\section{Differing Mental Models and the Futures of Libraries, Librarians, and Readers' Advisory}

\section{Bill Crowley}

Bill Crowley, PhD is Professor, Graduate School of Library and Information Science, Dominican University, River Forest, Illinois.

Correspondence to this column should be addressed to Laurel Tarulli, Librarian and Information Services Manager, Sacred Heart School of Halifax.; email: laureltarulli@yahoo.com.
Many of us struggle with determining the best way to represent our profession in libraries. How do we maintain our relevance and the value of our degreed professionals while managing increasing expectations from patrons, tax payers, and politicians? In RUSQ 54:4, Duncan Smith provided a thoughtful conversation on the future of readers' advisory services in his article "Readers' Advisory: The Who, the How, and the Why." Smith decided to write the article after reading Bill Crowley's 2014 article "Time to Rethink Readers' Advisory Education." Smith and Crowley, while both highly respected professionals in the library industry, believe in two very different readers' advisory paradigms and the role professionals and paraprofessionals play in this service. In an effort to provide insight into both mental models, Crowley agreed to provide his reflection on Smith's article, expanding on his original article and introducing the RUSQ readership to an alternate readers' advisory model. In particular, he wants us to ask the questions "is RA success determined by facts or perceptions?" and "is our current RA model the right model?" It's an exciting opportunity for all of us to have two such notable professionals offering their expertise and opinion on the future of RA, providing deep reflection, solid arguments, and reflection on their differing RA paradigms.—Editor

\section{TWO RA STORIES}

\section{IT, Precision, and the Readers' Advisory "Cookbook"}

Early in my years teaching Readers' Advisory Service at Dominican University's Graduate School of Library and Information Science (GSLIS) a student walked into my office waving a copy of the second edition of Joyce G. Saricks and Nancy Brown's Readers' Advisory Service in the Public Library. ${ }^{1}$ He opened the conversation by asking why I was using the volume in my course. I laughed and informed him that there was a shortage of textbook options. Unsatisfied, he informed me that the book was the reason he wasn't taking the RA class. When quizzed about his decision, the student explained he worked in a corporate information technology (IT) department. For him, Readers' Advisory Service in the Public Library was an imperfect version of what IT called a "cookbook" because the authors were trying to provide "recipes" or step by step directions for solving problems.

"But these readers advisory recipes are so imprecise" he stressed. "It's nothing like reference. If you get things right, it's probably more luck than anything else." 


\section{READERS' ADVISORY}

His complaint registered, the student left to return Readers' Advisory Service in the Public Library for a refund, leaving me pondering the true purpose of the Saricks and Brown RA "cookbook." As a former reference librarian, public/cooperative library administrator, and deputy state librarian, I had years of experience doing and managing reference and advising readers. I was also teaching two kinds of reference courses that semester. The standard RA approach of suggesting as many as six or ten volumes of "story" through the interview-and sometimes observing the reader check out only one or two books (if any)—was a stumbling block for some students. If post-Saricks and Brown readers' advisory work was so imprecise by reference's "give them the right answer and the source" benchmark, what was the real appeal of Readers' Advisory Service in the Public Library for the library profession?

\section{A Plea to Help Preserve RA Professionalism}

In 2014, shortly after the appearance of my Public Libraries article "Time to Rethink Readers' Advisory Education?" I received an email from a North American public library's head of RA telling me that she was going to send a link to the article to her staff. In our discussion she informed me that her director was in the process of eliminating the requirement for an MLIS for RA personnel. In the director's opinion, funding challenges had made professional librarianship a prized and limited resource that should be employed only in the library's priority areas. The RA head's hope was that the arguments made in "Time to Rethink" might change the director's mind. She confessed that it was a long shot but the lack of support for RA delivery by professional librarians in the library literature had made my article one of the few resources for tying RA to librarian professionalism.

Having spent much of my library career as a practitioner and educator defending librarian professionalism, I found this impending defeat for assigning the professionally educated to RA services to be particularly frustrating. After years of attempting to make RA a field worthy of respect, I found it galling to learn that yet another director viewed RA as a second class service beneath the purview of educated library professionals.

\section{RA Paradigms/Mental Models}

First, thanks to Column Editor Laurel Tarulli for amiably agreeing to consider a response to Duncan Smith's "The Who, the How, and the Why" Readers' Advisory column (summer 2015) critiquing my July/August 2014 Public Libraries' article "Time to Rethink Readers' Advisory Education?" From the start, it seemed appropriate to have the response address how differences regarding the appropriate aims of RA can result from our using diverging paradigms (mental models and lenses) to view the same RA activities. Smith adheres to the Saricks and Brown model of reading for recreation while I claim that model has limited appeal to directors and funders and assert the need RA to address, where feasible, public priorities such as literacy and learning (see below). Nevertheless, on rereading Smith's critique, it became abundantly clear that the integrity of his assessment actually buttressed the case for reforming RA through recognizing the limits of its techniques, goals, and applications. Saricks and Brown initially published their book in $1989^{4}$ — a full quarter of a century ago. By now this late twentieth century RA "innovation" ought to have diffused its value throughout librarianship. Instead, Smith reported that RA was so undervalued in libraries that many practitioners did not even receive adequate training. ${ }^{5}$ Consequently, the Saricks and Brown RA model can be considered a "stalled paradigm" requiring a "theoretical upgrade" to grow via enhancing its ability to influence library directors and the public officials, elected and appointed, who oversee library funding.

Human beings operate through paradigms or mental models which determine how they view and understand their worlds. This reality is described by Greer, Grover, and Fowler in their Introduction to the Library and Information Professions:

A paradigm is neither a new technology nor a new technique in doing a task or activity. It is a new way of perceiving what was known before. This new perception is so profound that it alters how we define a previously known truth ... a paradigm encompasses the values we have devised in making sense of the world. Paradigms specify what we see and ignore when viewing our reality. ${ }^{\top}$

In the next section this essay will consider the lack of endorsement of contemporary readers' advisory by library managers and public officials. Next, the Saricks and Brown RA paradigm will be discussed under the rubric of Standard Readers' Advisory. Components of an emerging alternative model of the library's RA role will then be offered under the heading Reformed Readers' Advisory. Each examination will begin with an analysis of the RA "problem" as defined by the model, followed by a consideration of the solutions the modeloffers. The reviews will conclude with an analysis of the paradigm's strengths and weaknesses. Finally, this column explores whether an interlanguage or "a negotiated evolving, mutually acceptable repertoire of common understandings about the world or aspects of the world"8 can be negotiated between the Standard Readers' Advisory and Reformed Readers' Advisory paradigms/models.

\section{PERCEPTIONS OF THE LIBRARY HELD BY PUBLIC OFFICIALS}

In a May 2014 a pro-public library article titled "Check Out the New Library: A Vital, Multiservice Hub for All Generations" appeared in Public Management, published for its members by the International City/County Management 
Association (ICMA). The article was the culmination of over five years of ICMA cooperation with public libraries. In it, Craig Gerhard, former county executive of Prince William County, Virginia, and Kira Hasbargen, senior management associate with ICMA, describe how many local officials perceive public libraries as simply "quiet places surrounded by books." According to the authors, many such officials lack knowledge of the way are libraries "providing highly relevant services and engaging directly with residents" through such programs as

- digital media labs;

- 3D printers;

- virtual and in-person homework help;

- Internet and information safety;

- GED and post-secondary education;

- résumé and interview skill building;

- job search centers; and

- language instruction. ${ }^{10}$

The reader will note that adult RA did not make this listing of "highly relevant services." Worse, the view of the library as an oasis for book lovers even blocks local public officials from interacting with librarians in ways perceived to be more valuable. "Our preconceived notions of what libraries 'are' have created barriers to engaging them in strategic problem solving and community building. Now is the time to step back into your library to recognize and strategically plan how libraries can help with community issues." ${ }^{11}$

This ICMA-sponsored article was linked to the Urban Libraries Council webpage as of the writing of this response. ${ }^{12}$ Although adult RA was ignored, the value of adults reading to their children and benefitting from literacy programs was emphasized. ${ }^{13}$ Clearly, other library goals generate more respect. As stressed by Sacramento Public Library Director Rivkah Sass, quoted in the Public Management article, "Education is what makes the difference. If people can read, they can learn. If people can learn, they can make informed decisions. By making informed decisions, people can participate in a democracy."14

Smith's article shared his strong concerns over libraries not providing their personnel with RA training and of library leaders underappreciating the value of books. Such issues can be addressed if and when readers' advisors demonstrate to library managers — and to local officials — that their work helps provide solutions to the "community issues" that are the priorities of such leaders.

\section{STANDARD READERS' ADVISORY}

\section{Statement of the Problem}

Smith sets out the Standard Readers' Advisory problem via his summary of the initial work of Saricks and Brown stating, "it was more than twenty-five years ago that Joyce Saricks and her coworker Nancy Brown realized that they had a problem. ... The fiction titles that were driving circulation lacked a classification framework that defined and grouped titles based on their similarities. There was no Dewey for fiction." ${ }^{15}$

\section{Summary of Standard Readers' Advisory Problem Solutions}

The value of the early work of Saricks and Brown in analyzing fiction RA practices, as well as developing and publicizing their service recipes, is commonly acknowledged. However, concerns develop when their solutions and goals are subjected to analysis. It turns out that the fundamental problem of contemporary RA may lie in the lack of a priority public purpose in the very definition presented in the third edition of Readers' Advisory Service in the Public Library "a patron-centered library service for adult leisure readers"16 According to Smith's recounting, Saricks and Brown's efforts at RA recipe formulations, albeit added to by others, form an extended process.

Through trial and error, these two practitioners developed a method for thinking about books in terms that mattered to readers. Appeal became the framework for conversations between library staff and readers that helped get those readers to their next book. The concept continues to be expanded with the development of appeal terms and frameworks for audiobooks and illustrations (picture books and graphic novels). ${ }^{17}$

Inherent in Smith's summary is the fact that the 1989 first and later editions of Readers' Advisory Service in the Public Library seem to offer two complementary solutions to the problem of matching readers with books. The first solution involves using the language of appeal. The second is redefining RA success in a manner different from the reference goal of a correct answer combined with the source of the information provided. It required a paradigmatic change of mind where reference standards were left behind as Saricks and Brown steered RA personnel toward the value of conditional matches, reassuring nervous practitioners that no advisor can be expected to provide a precise match of book to reader all the time.

Since 1989, the explicit goal of Standard Readers' Advisory has expanded to provide the reader, viewer, and listener with the type of story and story container (book, ebook, audiobook, video, etc.) that she or he requires at the time of the transaction. As outlined by Smith, this model sees as immaterial the master's degree from an American Library Association (ALA)-accredited program by involving "all" library personnel in the RA process. The implicit goal of Smith and the Standard Readers' Advisory model is that bringing both basic instruction and refining RA theory and practice to yet higher levels of effectiveness in meeting the reader-viewer-listener's needs will result in enhanced public and funder support for RA and the library that supplies it. 


\section{READERS' ADVISORY}

\section{Analysis}

Believing that Standard Readers' Advisory has resulted in better service to readers, viewers, and listeners is a perception, not a documented reality. To his credit, Smith has provided evidence demonstrating the limited reception by libraries of the Saricks and Brown approach, stating "our belief that we are providing very effective or effective RA service is aspirational and not the reality experienced by a majority of our readers"18

The present state of RA comes close to epitomizing the concept of mythic fact, something "made up of conflations of fact and fiction, understanding and misunderstanding, information and misinformation." ${ }^{19}$ In itself, this is not always a difficulty. As stressed in "Time to Rethink Readers' Advisory Education?" people operate on the basis of perceptions, not facts..$^{20}$ The true problem for RA lies in the reality that practitioner perceptions of its value and relevance are not often shared by library directors and funders. The library profession has long fooled itself into believing that simply providing more and better facts about great library services, even if these services are not priorities of decision makers, can somehow generate more positive views of the library. In the process, the profession has too-often suffered by ignoring the power of emotional connections to established priorities in the private and public lives of library managers, public officials, and the community as a whole. To complicate matters, such priorities can and do change. In the Pew Research Center publication From Distant Admirers to Library Lovers - and Beyond: At Typology of Public Library Engagement in America the point was stressed that "life stage and special circumstances are linked to increased library use and higher engagement with information"21 More specifically,

Deeper connections with public libraries are often associated with key life moments such as having a child, seeking a job, being a student, and going through a situation in which research and data can help inform a decision. Similarly, quieter times of life, such as retirement, or less momentous periods, such as when people's jobs are stable, might prompt less frequent information searches and library visits. ${ }^{22}$

Public officials often must deal with the cumulative effects of such "key life moments" in financially plagued and educationally challenged communities. If RA planners and practitioners can find ways to enhance connections with library, local decision makers, and community members, through addressing the problems keeping officials and residents up at night, they might well see a rise in recognition of the value of their services through enhanced ROEI or "Return on Emotional Investment." ${ }^{23}$ Circulation counts are simply outputs, not outcomes, and tend to please those already in support of RA. As stressed in my Public Libraries article fundamental decisions over support and staffing are made in the emotional realm and RA practitioners need to think more about perceptions and less about facts. For a service based on "appeal," it is self-defeating to ignore the reality of decisions based on perceptions and emotions.

On the level of the individual readers' advisor, using the Saricks and Brown appeal approach and defining the RA interview as "a conversation between the advisor and the reader about books" ${ }^{24}$ seems to be effective in developing an RA culture that accepts success in percentages when providing books of all types, videos, and music to customers. Dropping expectations for perfection clearly lessens anxiety in many new and experienced advisors.

As noted, in their drive to spread the word of the RA message, some practitioners and former practitioners such as Smith have devalued the worth of the master's degree from an American Library Association (ALA)-accredited program and privilege involving "all" library personnel in the RA process. It is a twenty-first century variation of the nineteenthcentury apprenticeship model for training library staff. Such a model may be appropriate for libraries not headed by a professional librarian and not otherwise employing those with a master's degree from an ALA-accredited program. However, it remains the case that degreed librarians are the most likely to ascend to library directorships in mid to large size public libraries. As such, they can be particularly supportive of areas of RA library work. Additionally, if you do not have professional librarians delivering the service, where are you going to get future RA managers unless you also deprofessionalize $R A$ department heads? For more on the implications of the apprenticeship model for librarianship the reader is directed to Hamerly and Crowley's recent consideration of professional education and its finding that advanced study in a field is still a requirement for defining a profession. ${ }^{25}$

\section{REFORMED READERS' ADVISORY}

\section{Statement of the Problem}

Reformed Readers' Advisory may be seen as a variety of approaches arising in response to a crisis ${ }^{26}$ in the Saricks and Brown RA paradigm. The problem lies in the reality that RA has failed to convince library directors and public officials that leisure reading does not require a higher goal and that it should be valued for itself as a library priority. Smith's own recountings strongly support the fact that effective RA is simply not a priority in America's public libraries or else RA training would be both mandatory and regularly provided. ${ }^{27}$

\section{Summary of Reformed Readers' Advisory Problem Solutions}

Reformed Readers' Advisory represents an RA paradigm still in the process of coalescing. Those seeking to identify and remove the negative consequences resulting from the perceived irrelevance of RA find themselves facing both external and internal RA impediments. The apparent lack of connection of RA with the goals of local government funders with the possibility of thereby increasing their support from such 
sources has already been addressed in the analysis of Gerhart and Hasbargen's "Check Out the New Library: A Vital, Multiservice Hub for All Generations." ${ }^{28}$ The internal RA issue, since Nancy Brown has largely withdrawn from the "conversation," results from the unique status held by co-appeal developer Joyce G. Saricks. Her continuing influence may be gauged by the RA column "We Owe Our Work to Theirs: Celebrating the Twenty-Fifth Anniversary of Reader's Advisory Service in the Public Library." ${ }^{29}$ This column summarizes an exceptional regard and a strong, continuing influence.

One indicator of a stalled RA paradigm is the lack of theoretical upgrades on fundamental issues. In the case of Reformed Readers' Advisory, only a small number of recognized theorists have written on RA problems with their analyses largely in refereed journals. ${ }^{30}$ Unassailable RA technique with insufficient theory is not effective tacit knowledge. It is problematic tacit ignorance that obscures the need for RA professional tacit knowledge to support the goals, often learning or educational, of the significant players in the life of the public and academic library. ${ }^{31}$

\section{Analysis}

Reformed Readers' Advisory advocates believe that all supporters, for an understanding of the "problem" facing contemporary RA, inevitably need to accept several realties, including

1. "setting aside of comforting misconceptions is important in any useful discussion of how to advance the cause of RA, ${ }^{, 32}$ and

2. RA "must be justified by its positive effects on the entire library program" even as it creates "a building-wide or organization-wide constituency."33

As noted, the comforting misconception that developing ever-better ways of connecting readers with books will somehow enhance external funder and internal library support is a mythic fact. One can agree with Smith that "for a majority of our regular and long-term users, it is the primary reason they use and value their library." ${ }^{44}$ However, library directors and funders have their own priorities and RA has not been seen as supporting these aims. To specifically apply to RA the words of Stenstrom and Haycock, library credibility is lost through "the inability of librarians to adapt library programs and services to meet the demands of changing government mandates." ${ }^{35}$ Although Smith is correct that reading is undoubtedly the primary cause of public library use, the Great Recession of 2007 has taught us that advocating pleasure reading does not seem to be sufficient to secure or defend funding.

The primary weakness of Reformed Readers' Advisory lies in the reality that it requires practitioners to demonstrate to library directors and local officials how RA can advance their agendas and is thus worthy of support. This requires expertise that may not be included in the average RA skill set but may well be present in practitioners with a master's degree from an ALA-accredited program which offers marketing and/or advocacy courses.

\section{COMMONALITIES OF STANDARD READERS' ADVISORY AND REFORMED READERS' ADVISORY?}

It is to be recalled that the author has promised to examine whether an interlanguage or "a negotiated evolving, mutually acceptable repertoire of common understandings about the world or aspects of the world" 36 exists or can be negotiated between the Standard Readers' Advisory and Reformed Readers' Advisory paradigms/models. Because this column has at least a bi-national readership I have suspended the vital requirement of responding to local priorities by identifying a research-identified reading problem that can be a test of whether the paradigms can find common ground. As Becker has observed, "agreeing on what objects are, what they do, and how they can be used makes joint activity much easier." 37

The problem, as outlined by the National Center for Public Policy and Higher Education and the Southern Regional Education Board, is

Every year in the United States, nearly 60 percent of first-year college students discover that, despite being fully eligible to attend college, they are not academically ready for postsecondary studies. After enrolling, these students learn that they must take remedial courses in English or mathematics, which do not earn college credits.... Even those students who have done everything they were told to do to prepare for college find, often after they arrive, that their new institution has deemed them unprepared. ${ }^{38}$

Inherent in my article "Time to Rethink Readers' Advisory Education?" is that a concentration on the learning benefits of sheer reading volume (leisure reading) will set the stage for academic, public, and school librarians to be seen as helping address a clear national problem. To the extent that Smith, as a representative of Standard Readers' Advisory, endorses the value of assisting in such priority work, there is a clear point of RA convergence. Additionally, Smith's argument for adapting successful reference learning approaches to RA is commendable and potentially effective. However, it must be understood that the nature of so much of RA will never allow it to approach the reference goal of the right answer and its source.

Since Smith concluded his article with a quote from a writer (poet) I will end this essay with a particularly relevant claim from the literary agent Noah Lukeman, "we must remember that reading is as much about education as it is entertainment." "Education" is a concept that can include many of the community priorities of local officials. It may 


\section{READERS' ADVISORY}

even ensure that adult RA is included the next time Public Management ${ }^{40}$ lists the resources that libraries can bring to addressing prominent local problems.

\section{References}

1. Joyce G. Saricks and Nancy Brown, Readers' Advisory Service in the Public Library (Chicago: American Library Association, 1997).

2. Bill Crowley, "Time to Rethink Readers' Advisory Education?" Public Libraries 53, no. 4 (July/August 2014): 37-43.

3. Laurel Tarulli and Duncan Smith, "Readers' Advisory: The Who, the How, and the Why," Reference \& User Services Quarterly 54, no. 4 (Summer 2015): 11-16.

4. Joyce G. Saricks and Nancy Brown, Reader's Advisory Service in the Public Library (Chicago: American Library Association, 1989).

5. Tarulli and Smith, "Readers' Advisory," 12.

6. Henry E. Hale, "Civilizations Reframed: Toward a Theoretical Upgrade for a Stalled Paradigm," Journal of Civilization Studies 1, no. 1 (January 2014): 1.

7. Roger C. Greer, Susan G. Fowler, and Robert J. Grover, Introduction to the Library and Information Professions (Santa Barbara: CA, 2013), 35-36.

8. Bill Crowley, Spanning the Theory-Practice Divide in Library and Information Science (Lanham, MD: Scarecrow, 2005), 204.

9. Craig Gerhart and Kira Hasbargen, "Check Out the New Library: A Vital, Multiservice Hub for All Generations," Public Management 96, no. 4 (May 2014): 6-9.

10. Ibid., 7 .

11. Ibid.

12. "News: Check Out the New Library," Urban Libraries Council, May 7, 2014, www.urbanlibraries.org/check-out-the-new-library -news-156.php.

13. Gerhard and Hasbargen, "Check Out the New Library," 9

14. Ibid.

15. Tarulli and Smith, "Readers' Advisory," 13

16. Joyce G. Saricks, Readers' Advisory Service in the Public Library 3rd ed. (Chicago: American Library Association, 2005), 1.

17. Tarulli and Smith, "Readers' Advisory," 13.

18. Ibid., 12.

19. David R. Maines, Jeffrey C. Bridger, and Jeffrey T. Ulmer, "Mythic Facts and Park's Pragmatism: On Predecessor-Selection and Theorizing in Human Ecology," Sociological Quarterly 37, no. 3 (1996), 522.

20. Crowley, "Time to Rethink," 41.

21. Kathryn Zickuhr, Kristen Purcell, and Harrison Rainie, From Distant Admirers to Library Lovers-And Beyond: A Typology of Public
Library Engagement in America (Pew Research Center, May 2014), www.pewinternet.org/files/2014/03/PIP-Library-Typology -Report.pdf.

22. Ibid.

23. Bill Crowley, "Know Your ROEI," Library Journal 135, no. 3 (February 15, 2010): 34-35

24. Saricks, Readers' Advisory Service in the Public Library, 75.

25. Don Hamerly and Bill Crowley, "Sustaining Professionalism in the Fields of Library and Information Studies," Library Philosophy and Practice, paper 1231 (2014), http://digitalcommons.unl.edu/ libphilprac/1231

26. Thomas S. Kuhn, The Structure of Scientific Revolutions (Chicago: University of Chicago Press, 1970), 84.

27. Tarulli and Smith, "Readers' Advisory," 12.

28. Gerhart and Hasbargen, "Check Out the New Library," 7-9.

29. Laurel Tarulli and Neal Wyatt, "We Owe Our Work to Theirs: Celebrating the Twenty-Fifth Anniversary of Reader's Advisory Service in the Public Library," Reference \& User Services Quarterly 54, no. 2 (Winter 2014): 24-30.

30. Crowley, "Time to Rethink," 42-43.

31. Bill Crowley, "Tacit Knowledge, Tacit Ignorance, and the Future of Academic Librarianship," College \& Research Libraries 62, no. 6 (November 2001): 581.

32. Bill Crowley, "Taught At the University on A Higher Plane than Elsewhere': The Graduate Education of Readers' Advisors," in Readers Advisors Companion, edited by Kenneth D. Shearer and Robert Burgin (Englewood, CO: Libraries Unlimited, 2001),

33. Bill Crowley, "Rediscovering the History of Readers' Advisory Service" Public Libraries 44, no. 1 (January/February 2005): 40.

34. Tarulli and Smith, "Readers' Advisory," 15

35. Cheryl Stenström and Ken Haycock, "Influence and Increased Funding in Canadian Public Libraries: The Case of Alberta in Fiscal Year 2009-10," Library Quarterly: Information, Community, Policy 84, no. 1 (January 2014): 52

36. Crowley, Spanning the Theory-Practice Divide, 204.

37. Howard S. Becker, Tricks of the Trade: How to Think about Your Research While You're Doing It (Chicago: University of Chicago Press, 1998), 50

38. Nancy Shulock and Patrick M. Callan, Beyond the Rhetoric: Improving College Readiness through Coherent State Policy (San Jose, CA: National Center for Public Policy and Higher Education, 2010), 1.

39. Noah Lukeman, The First Five Pages: A Writer's Guide to Staying out of the Rejection Pile (New York: Simon \& Schuster, 2000), 58.

40. Gerhart and Hasbargen, "Check Out the New Library," 6-9. 